\title{
Biota of a Temperate Shallow Water Reef
}

\author{
JEANETTE E. WATSON
}

\begin{abstract}
Watson, J. E. Biota of a temperate shallow water reef. Proc. Linn. Soc. N.S. W. 103 (4), (1978) 1979: 227-235.

This study describes the total flora and fauna of a small $\left(1 \mathrm{~m}^{2}\right)$ but representative area of temperate water reef $23 \mathrm{~m}$ deep near Sydney, New South Wales. Excluding Foraminifera, the biota totalled 150 species comprising 29 algal, 120 invertebrate and 1 fish species. Hydroids are dominant in terms of species $(13 \%)$ and sessile invertebrates comprise $51 \%$ of community biomass and $61 \%$ of species. Algae comprise $19 \%$ of species and $36 \%$ of community biomass. Populations of numerable animals are dominated by polychaetes $(18 \%)$ and amphipods $(17 \%)$. The sample yielded 8 new species, one new genus, extended the Australian provincial distribution of 17 species and provided 4 new records for Australia.

Jeanette E. Watson, Honorary Associate, National Museum of Victoria, 285-321 Russell Street, Melbourne, Australia 3000; manuscript received 20 June 1978, revised manuscript accepted 18 October 1978.
\end{abstract}

\section{INTRODUCTION}

In recent years there have been a number of studies on the species composition, distribution and ecology of the soft bottom littoral and sublittoral estuarine communities of the south-eastern Australian coastline (King et al., 1971; Stephenson et al., 1974; Poore \& Rainer, 1974; Hutchings \& Recher, 1974). There are however, few published reports upon the epibiota of sublittoral reefs. These include several detailed studies of the ecology of benthic Algae in South Australian waters by Shepherd and Womersley $(1970,1971,1976)$, and generalized accounts of the benthic ecology of Gulf St. Vincent and Investigator Strait in South Australia (Shepherd \& Sprigg, 1976; Richardson \& Watson, 1975a, 1975b), of Westernport Bay in Victoria (Smith et al., 1975), and of the central New South Wales coast near Sydney (Laxton, 1976, 1977; Jones, 1977. None of these studies has, however, been directed towards a complete analysis of the epibiota at any one sampling site.

As part of a wider survey involving pollution studies at other localities on the central New South Wales coastline, the biota of a flat-topped sandstone reef in an unpolluted environment at $23 \mathrm{~m}$ depth was sampled at a site $500 \mathrm{~m}$ east of Jibbon Bombora in the ocean off Port Hacking ( $34^{\circ} 01^{\prime} 20^{\prime \prime} \mathrm{S} ., 151^{\circ} 14^{\prime} 20^{\prime \prime} \mathrm{E}$.) in September 1976.

\section{SAMPLING METHODS}

Following preliminary inspection, a site representative of the biota of the reef top was selected for sampling. A hoop of $0.33 \mathrm{~m}^{2}$ was then thrown randomly on the site and the enclosed biota completely scraped into a fine mesh bag. This was repeated to give a total sampling area of $1 \mathrm{~m}^{2}$.

The samples were later sorted under the microscope to species level and individual organisms counted. Colonial organisms were drained, blotted, and estimated as damp weight. This method of estimation of biomass was adopted since damp weighing does not destroy specimens which may later require detailed taxonomic examination.

Only Foraminifera were not examined in detail. 


\section{RESULTS}

The list of species, together with numbers of individuals animals and the biomass of larger colonial organisms is given in the Appendix. Smaller colonial organisms are assigned a rank order of abundance from 1 (rare); 2 (common), to 3 (abundant) .

The biota of the total sampling area of $1 \mathrm{~m}^{2}$ comprises 150 species, of which 29 (19\%) are Algae belonging to 29 genera. One hundred and twenty species are invertebrates, referable to at least 100 genera (not including sponges), and there is 1 species of fish. In terms of numbers of species, hydroids are the most abundant invertebrate group with 19 species ( $13 \%$ of total invertebrate species present), followed by Bryozoa (15 species, 10\%), polychaetes (15 species, 10\%), amphipods (12 species, $8 \%$ ), sponges (11 species, $7 \%$ ), bivalves (10 species, $7 \%$ ), and gastropods ( 8 species $5 \%$ ). The collection contains 155 invididual non-colonial animals with the polychaetes contributirig the greatest number (28 invididuals, $18 \%$ ), followed by amphipods (27 individuals, 17\%), gastropods (26 individuals, 17\%), bivalves (25 individuals, $16 \%$ ), and ophiuroids (17 individuals, $11 \%$ ).

The colonial polychaetes Phyllochaetopterus socialis, Serpula vermicularis and Filograna implexa, with relative abundances of (3), (2) and (1) respectively, would, if counted as individuals, considerably augment the polychaete population.

Total biomass of Algae and animals amounts to some $700 \mathrm{~g}$ damp weight. In terms of biomass, the sponges, with $283 \mathrm{~g}$ ( $40 \%$ of biomass) are the most abundant group, followed by Algae with $255 \mathrm{~g}$ (36\% of biomass), and the single alcyonarian colony, Capnella gaboensis, with $36 \mathrm{~g}$ ( $5 \%$ of biomass). The remaining biomass is made up of gastropods $(3 \%)$, one species of ascidian, Polycarpa pedata $(3 \%)$, bivalves and Bryozoa (each $2 \%$ ), and hydroids ( $1 \%$ ).

The more important groups of the biota are discussed below:

Algae

Of the 29 algal species recorded, 26 are red Algae and the remainder brown. All are small, low growing, turf-like species. Three are new records for New South Wales and include Antithamnion pinnafolium Wollaston, previously unknown outside South Australia, Anotrichum crinitum (Kuetzing) Baldock, which has a recorded distribution of southern Australia and New Zealand, and Schottera nicaeense (Duby) Guiry and Hollenberg, a Mediterranean species. Two as yet undescribed species, Propagula sp., and Mediothamnion sp., only recently discovered in Port Phillip Bay, Victoria, were also present in the sample. Several other species may also represent new taxa, but the material is insufficient for determination.

\section{Sponges}

This group comprises 11 species in 4 families. Only one, Callyspongia sp., a small grey dish-shaped sponge, could be identified to genus. The next most abundant sponge is an erect orange-coloured species belonging to the Raspailiidae. All are common sponges along this part of the New South Wales coastline.

\section{Hydroids}

The shallow water hydroid fauna of the New South Wales coast is known only from records of Bale $(1884,1888)$ and from the reports of the "Thetis" Expedition (Ritchie, 1911) and occasional incidental references in the literature. The 19 species of hydroids in the collection include 2 undescribed species, one belonging to the genus Hebella, and the other to Antennella. There are also 6 new records for the central east coast of Australia. Several of the newly recorded species are abundant in the sample and include the large plumose hydroid, Plumularia asymmetrica Bale, formerly recorded from the Great Australian Bight (Bale, 1915; Watson, 1973); Scoresbia daidala Watson, a small, obligatory epiphyte on the brown alga Zonaria crenata J. 
Agardh, recorded once previously from the type locality in Gulf St. Vincent, South Australia, Monostaechus quadridens McCrady, formerly recorded from Queensland (Pennycuik, 1959), and Sertularia olseni Watson, a hydroid associated with sponges, recorded once, from the type locality in the Great Australian Bight (Watson, 1973).

Only 2 of the hydroids, Tubularia australis Stechow, and Eudendrium sp., are athecate species. Of the 17 thecate species, 13 are small epiphytes growing among the algal turf, and the remainder, with the exception of the epilithic Plumularia asymmetrica, are epizooites, growing upon tubiculous polychaetes or on other hydroids.

\section{Alcyonaria}

This group is represented by 3 species, including one large colony of Capnella gaboensis Verseveldt. Although only recently described (Verseveldt, 1977), this is a common shallow water alcyonarian of New South Wales coastal reefs.

\section{Bryozoa}

The bryozoan fauna of the New South Wales coastline is not well known, and of the 12 species represented in the sample, 5 are new records for this part of the Australian coastline. There are 7 species of crustose (membraniporiform) Bryozoa, 4 erect jointed (cellariiform) species and 1 erect (vinculariiform) species. The cellariiform species, Crisia acropora Busk and Emma triangula Hastings, are among the new locality records and are also the most abundant species in the sample. C. acropora is known from Bass Strait (Busk, 1875) and E. triangula is known from this locality as well as from New Zealand (Hastings, 1939).

\section{Polychaetes}

Of the 15 species of polychaetes present, tubiculous forms are the dominant group in terms of numbers and include 5 species of serpulids. Phyllochaetopterus socialis Claparède is the most abundant polychaete in the sample (abundance (3)), the clustered tubes providing substrate for a number of small sessile species, including hydroids and Bryozoa. The cosmopolitan Nematonereis unicornis Grube is recorded for the first time in Australian waters. The nearest locality record for this species is the Indo-west Pacific.

Approximately half of the polychaete species and the major part of the polychaete population are filter feeders, including all of the tubiculous species. The remainder may be either omnivores or predators but there is little information on their feeding habits.

\section{Mollusca}

The shelled molluscs are all small reef dwelling species well known from the literature. The sample comprises 26 gastropods belonging to 8 species and 25 individuals of 10 bivalve species.

The predatory boring gastropod, Torvamurex denudatus (Perry) is the most abundant mollusc with 11 individuals in the sample. Since few bored bivalve shells were found, it seems likely that this species may be an unspecific predator or scavenger.

The algal browsing seahare, Aplysia sydneyensis Sowerby, is represented by one specimen. The type locality of this circumglobal species is Port Jackson. The remaining 2 species of opisthobranchs are undescribed species of the genera Philine and Trapania, the latter being a first record of this cosmopolitan genus for Australia.

\section{Amphipoda}

There are 2 undoubted, and possibly 5 additional undescribed species, reflecting the poor state of knowledge of the taxonomy of the group. Mallacoota subcarinata 
(Haswell), commonly occurring throughout south-eastern Australia, is the only species whose distribution is known. Half of the 11 amphipod species and the tanaid Paratanais cf. ignotis (Chilton) are tubiculous forms which are usually responsible for stabilization of substrate, accumulating silt and detritus in and around their tubes.

\section{Isopoda}

Of the 3 species of isopods recorded, only one, Cymodoce aspersa (Haswell), whose type locality is Port Jackson, has been fully described. A single juvenile female is probably Cilicaeopsis granulata (Whitelegge). Jibbon Head, adjacent to the sampling site, is one of the localities where this species was collected by Whitelegge (1902). The third species, represented in the sample by 2 adult males is an undescribed species which may also be worthy of separate generic status (W. Seed, pers. comm.). A similar, unnamed specimen was recorded from Masthead Island on the Great Barrier Reef by Baker (1926) .

\section{Ophiuroidea}

The 4 species of ophiuroids include one new genus and one new record for the Australian east coast. The undescribed genus is an amphiurid related to the cosmopolitan shallow water species Amphipholis squamata (Delle Chiaje) (A. Baker, pers. comm.), and the new record is Ophiacantha alternata A. M. Clark, a small sublittoral form previously known from Port Phillip Bay, Victoria. The 2 other species, Ophioactis resiliens Lyman and Ophiothrix caespitosa Lyman are common components of the immediate sublittoral algal-sponge-bryozoan fauna of temperate Australia.

\section{Holothuroidea}

Of the 3 species identified, Pentacta australis Ludwig is a common form widely distributed along the Australian coastline. The other two species comprise Neocucumis ? watasei (Oshima), known only from Japan, and an undescribed species of Thyone.

\section{Other Species}

The brachiopod Magellania flavescens (Lamarck) represented by one small specimen, is a widely, but sparsely distributed species in shallow ocean waters of temperate Australia. Balanus trigonus (Darwin) is one of the commonest barnacles of the sublittoral of the New South Wales coastline, where it has been dredged from depths of up to $108 \mathrm{~m}$ (Pope, 1945). The ascidian Polycarpa pedata Herdman, is a very common solitary ascidian of the sublittoral of the south-eastern coast. It frequently grows in association with the stalked ascidian, Pyura spinifera (Quoy \& Gaimard) (J. E. W. unpub.).

\section{DISCUSSION}

The 150 species belonging to 104 genera include a new genus of ophiuroid and a probable new genus of isopod. Eight are probable new species (2 hydroids, 2 opisthobranchs, 2 amphipods, 1 isopod and 1 holothurian). The ranges of 4 algal species, 6 hydroids, 5 bryozoans and 1 ophiuroid are extended to the temperate east coast from the cool temperate southern region and the range of one isopod species is extended southwards from the Great Barrier Reef. There are 4 new records for Australia with the discovery of the cosmopolitan polychaete Nematonereis unicornis, the holothurian Neocucumis ?watasei, previously recorded from Japan, the opisthobranch, Trapania sp., and the Mediterranean red alga, Schottera nicaeense. This number of new species and new records is all the more remarkable when the small size of the sampling area, and its situation in a region considered to be relatively well known scientifically, is taken into account. 
With the exception of Callyspongia, the larger of which was $10 \mathrm{~cm}$ in diameter, and the ascidian Polycarpa pedata, the biota comprised small to very small organisms, most of which are dependent upon the algal turf for substrate, food and shelter. The algal community is dominated by small filamentous rhodophytic species; there are only 3 small species of brown Algae, and green Algae are absent.

Sessile invertebrates comprise $51 \%$ of the biomass of the community and $61 \%$ of the species present. Algae account for $36 \%$ of the biomass and $19 \%$ of the species; algal cover was subjectively estimated at $50 \%$ of the sampling area.

Analysis of community trophic structure shows that the greatest contribution to the animal community biomass $(48 \%)$ is by the suspension feeding component, dominated by sponges. In terms of species, however, carnivores, mainly microcarnivores, comprise the largest single feeding class with $42 \%$ of the total species present. Using photographic techniques in benthic studies off the New South Wales coastline, Laxton $(1976,1977)$ and Jones $(1977)$, found that microcarnivores contributed the greatest percentage cover on most rocky substrates in areas where water turbidity is high. Pequengnat (1964), using species and population counts, found that suspension feeders were the most abundant components of a Californian reef-top habitat. Analysis of the present very limited sample supports Laxton's findings; it is quite likely however, that habitat or geographical differences as well as sampling methods may lead to widely varying results.

The new locality records from this sample provide further information upon the biogeographic affinities of south-eastern Australia with the Indo-Pacific and Japan. The sample also provides additional evidence for the close relationship of the Australian Peronian with the southern Flindersian Province west of Bass Strait.

\section{ACKNOWLEDGEMENTS}

The assistance of the following specialists who identified material and gave helpful advice and information is gratefully acknowledged: Dr. A. N. Baker, National Museum of New Zealand, Wellington, New Zealand (ophiuroids), Mr. R. Burn, Mr. D. A. Staples and Ms. S. Boyd, National Museum of Victoria, Melbourne (opisthobranchs, pycnogonids and bivalves respectively), Dr J. D. Kudenov and Dr G. C. B. Poore, Marine Studies Group, Ministry for Conservation, Melbourne (polychaetes and Crustacea), Messrs C. O'Brien and J. Lewis, Botany Department, University of Melbourne (Algae), Dr F. W. E. Rowe, Australian Museum, Sydney (holothurians), Mr W. Seed, Department of Biology, Royal Melbourne Institute of Technology (isopods), Dr J. Verseveldt, Rijksmuseum van Natuurlijke Historie, Leiden, Netherlands (Alcyonaria), and Dr A. Ayling and Mr R. Whitten, University of Auckland, New Zealand (sponges and Bryozoa). The author also wishes to thank Mr D. A. Staples and Mr H. Habgood for assistance with collection of material under difficult conditions. 


\section{References}

BAKER, W. H., 1926. - Species of the isopod family Sphaeromidae from eastern, southern and western coasts of Australia. Trans. R. Soc. S. Aust., 50: 247-279.

BALE, W. M., 1884. - Catalogue of Australian Hydroid Zoophytes. Sydney: Australian Museum.

1888. - On some new and rare hydroids in the Australian Museum collection. Proc. Linn. Soc. N.S.W., 3: 745-799.

1915. - Report on the Hydroida collected in the Great Australian Bight and other localities. Part III. Biol. Res. F.I.S. "Endeavour", 3 (5) : 241-366.

Busk, G., 1875. - Catalogue of the Cyclostomatous Polyzoa in the Collection of the British Museum. London: British Museum (Nat. Hist.).

Clark, A. M., 1966. - Port Phillip Survey 1957-1963. Echinodermata. Mem. Natn. Mus. Vict., $27: 289$. 351 .

Grube, A. E., 1840. - Actinien, Echinodermen und Wurmer des Adriatischen- und Mittelmeetes . . Königsberg.

Hastings, A. B., 1939. - Notes on some cellularine Polyzoa (Bryozoa). Novitates Zoologicae, XLI: 321 344 .

Haswell, W. A., 1881. - On some new Australian marine Isopoda. Proc. Linn. Soc. N. S. W., 5 (1) : 470 481 .

Hutchings, P. A., and Recher, H. F., 1974. - The fauna of Careel Bay with some comments on the ecology of the mangrove and seagrass communities. Aust. Zool., 18 (2) : 99-128.

JONES, A. R., (ed.), 1977. - An ecological survey of the nearshore waters east of Sydney, N.S.W. 1973-75. Sydney: Australian Museum.

KING, R. J., Black, J. H., and Ducker, S. C., 1971. - Port Phillip Survey 2. Intertidal ecology of Port Phillip Bay with systematic list of plants and animals. Mem. Natn. Mus. Vict., 32: 93-128.

Laxton. J. H., 1976. - Ocean disposal of sewage effluent from coastal cities. A biologist's viewpoint. Report to the Department of Public Works, New South Wales, Sydney.

1977. - Boulder Bay Ocean Outfall. Report on Environmental Impact on marine communities. Report for the Hunter District Water Board, Newcastle.

Lyman, T., 1879. - Ophiuridae and Astrophytidae of the "Challenger" Expedition. II. Bull. Mus. Comp. Zool. Harvard, 6 (2): 17-83.

Pennycuik, P. R., 1959. - Faunistic records from Queensland. Part V. Marine and brackish water hydroids. Pap. Dep. Zool. Univ. Qld, 1 (6) : 141-210.

Pequegnat, W. E., 1964. - The epifauna of a Californian siltstone reef. Ecology, 45 : 272-283.

Poore, G. C. B., and Rainer, S., 1974. - Distribution and abundance of soft bottom molluscs in Port Phillip Bay, Victoria, Australia. Aust.J. Mar. Freshwat. Res., 25:371-411.

Pope, Elizabeth C., 1945. - A simplified key to the sessile barnacles found on the rocks, boats, wharf piles and other installations in Port Jackson and adjacent waters. Mem. Aust. Mus., 21 (6) : 351-372.

Richardson, Joyce R., and WAtSOn, JeAnette E., 1975a. - Locomotory adaptations in a free-lying brachiopod. Science, 189: 381-382.

- 1975b. - Form and function in a recent free living brachiopod Magadina cumingi. Palaeobiology, 1: 379-387.

Ritchie, J., 1911. - Hydrozoa (Hydroid zoophytes and Stylasterina) of the "Thetis" Expedition. Mem. A ust. Mus., 4: 807-869.

Shepherd, S. A., and Womersley, H. S. B., 1970. - The sublittoral ecology of West Island, South Australia. 1. Environmental features and algal ecology. Trans. R. Soc. S. Aust., 94: 105-138.

1971. - Pearson Island Expedition, 1969. 7. The subtidal ecology of benthic algae. Trans. R. Soc. S. Aust., 95 (3) : 155-167.

1976. - The subtidal algal and seagrass ecology of St. Francis Island, South Australia. Trans. R. Soc. S. Aust., 100 (4) : 177-191.

SHePherd, S. A., and SPrigg, R. C., 1976. - Substrate, sediments, and subtidal ecology of Gulf St. Vincent and Investigator Strait. Natural History of the Adelaide Region. Adelaide: Royal Society of South Australia Inc.

Smith, B. J., Coleman, N., and Watson, Jeanette E., 1975. - The invertebrate fauna of Westernport Bay. Proc. R. Soc. Vict., 87 (1) : 149-156.

Sowerby, G. B., 1869. - [Aplysia] Conchologia Iconica: XVII, Pl. 7, Fig. 31. London.

Stephenson, W., Williams, W. T., and Cooke, S. D., 1974. - The benthic fauna of soft bottoms, southern Moreton Bay. Mem. Qld Mus., 17 (1) : 73-123.

Verseveldt, J., 1977. - Australian Octocorallia (Coelenterata). Aust. J. Mar. Freshwat. Res., 28: 171240.

Watson, Jeanette, E., 1973. - Pearson Island Expedition 1969. 9. Hydroids. Trans. R. Soc. S. Aust., 97 (3) : $153-200$.

Whitelegge, T., 1902. - Scientific results of the trawling expedition of H.M.C.S. "Thetis". Crustacea Part III. Isopoda Part II. Sydney: Australian Museum.

Proc. Linn. Soc. N.S.W., 103 (4), (1978) 1979 


\section{APPENDIX}

\section{LIST OF SPECIES}

Numbers after the species name represent individual organisms.

Numbers in parentheses are an estimation of rank order of abundance of colonial organisms and algae, $(1)=$ rare, $(2)=$ common, $(3)=$ abundant.

New records are marked*.

Probable new genera or new species are marked ${ }^{+}$.

\section{ALGAE}

Phaeophyta :

Halopteris platycena Sauvageau

Dictyota alternifida J. Agardh

Zonaria sinclairii Hooker \& Harvey

Rhodophyta:

Delisea fimbriata (Lamouroux) Mont.

Cheilosporum sagittatum (Lamouroux) Aresch.

Jania sp.

Thamnoclonium sp.

Callophyllis sp.

* Schottera nicaeense (Duby) Guiry \& Hollenberg

Glioderma sp.

Aglaothamnion sp.

*Anotrichium crinitum (Keutzing) Baldock

*Antithamnion pinnafolium Wollaston

Balliella sp.

Callithamnion sp.

Ceramium sp.

*Mediothamnion sp.

Platythamnion sp.

*Propagula sp.

Pleonosporium sp.

Spongoclonium sp.

Acrosorium decumbens (J. Ag.) Kylin

Phycodris sp.

Dasya wilsonis J. Agardh

Heterosiphonia australis (J. Ag.) De Toni

Aphanacladia sp.

Amplisiphonia sp.

Dasyclonium incisum (J. Ag.) Kylin

Polysiphonia sp.

\section{INVERTEBRATA}

Porifera :

Callyspongiidae Callyspongia sp.

Raspailiidae

Suberitidae

Hydroida :

Spongiidae

Athecata:

Tubularia australis Stechow

Eudendrium sp.

Thecata:

${ }^{*}$ Clytia sp.

Obelia sp.

Hebella scandens (Bale)

${ }^{+}$Hebella sp.

Hincksella cylindrica (Bale)

Halecium sessile Norman

*Halecium? fragile Hodgson

Halecium delicatulum Coughtrey

*Scoresbia daidala Watson

Proc. Linn. Soc. N.S.W., 103 (4), (1978) 1979 
Sertularella simplex Coughtrey

*Amphisbetia olseni Watson

Antennella secundaria Gmelin

+Antennella sp. 2

${ }^{*}$ Monostaechus quadridens McGrady

Plumularia spinulosa Bale

Plumularia obliqua Saunders

*Plumularia asymmetrica Bale

Actinaria :

Anemone sp.

Alcyonaria :

Capnella gaboensis Verseveldt

Alcyon aria sp. 2

Alcyonaria sp. 3

Bryozoa:

*Aetea anguina (Linnaeus)

Chaperia cervicornis (Busk)

Caberea helicina Hastings

*Emma triangula (Hastings)

*Celleporaria intermedia (MacGillivray)

Celleporaria (Sinuporaria?) hastigera

Discopora vultur (Hincks)

Smittoidea acaroensis (Busk)

Celleporina sp.

*Crisia acropora Busk

Bicrisia edwardsiana (d'Orbigny)

*Pustulopora? intricaria (Busk)

"Retepora"sp.

Scuticella ventricosa (Busk)

Amathia biseriata Krauss

Polychaeta:

Ophiodromus sp.

Haplosyllis spongicola Grube

Pionosyllis sp.

Typosyllis sp.

Exogone sp.

Platynereis australis (Schmarda)

*Nematonereis unicornis (Grube)

Phyllochaetopterus socialis Claparède

Idanthyrsus pennatus (Peters)

Branchiomma nigromaculata (Baird)

Hydroides? brachycantha Rioja

Pomatostegus polytrema (Philippi)

Filograna implexa Berkley

Serpula vermicularis Linnaeus

Spirobranchus giganteus (Pallas)

1

2

1

8

1

1

(3)

(3)

Sipunculida

Sipunculid sp.

Nemertina :

Nemertine sp.

Brachiopoda:

Magellania flavescens (Lamarck)

Gastropoda :

Torvamurex denudatus (Perry)

Dentimitrella lincolnensis (Reeve)

Cypraea sp.

Notosinister maculosa (Hedley)

Mitra carbonaria Swainson

Austrosassia parkinsoniana (Perry)

Vermicularia sp.

Murexsul brazieri (Angas) 
Ophisthobranchia:

Aplysia sydneyensis Sowerby

+ Philine sp.

+Trapania sp.

Bivalvia:

Dosinia sp.

Venerupis exotica Lamarck

Hiatella australis (Lamarck)

1

Diplodonta globulosa A. Adams

Marikelliia solida (Angas)

Cardita calyculata (Linnaeus)

Atrina tasmanica (Tenison Woods)

Lanistina impacta (Hermann)

Lima nimbifer Iredale

Trichomya hirsuta (Lamarck)

Crustacea :

Amphipoda :

Photis sp.

Aora sp.

Gammaropsis sp.

Amphithoid sp. 1

Amphithoid sp. 2

Cerapus sp.

${ }^{+}$Phlianthid sp.

${ }^{+}$Liljeborgia sp.

Mallacoota subcarinata (Haswell)

Tethygeneia cf. elanora Barnard

? Corophiid sp.

Amaryllis macrophthalmus (Haswell)

Tanaidacea :

Paratanais cf. ignotus (Chilton)

Isopoda :

Cymodoce aspersa (Haswell)

${ }^{+}$cf. Cymodoce sp.

Cilicaeopsis granulata (Whitelegge)

1

3

1

1

4

2

1

4

7

Brachyura :

Plagusia chabrus (Linnaeus)

Halicarcinus ovatus Stimpson

Micippa tuberculosa (H. Milne Edwards)

Leptomithrax sternocostulatus (H. Milne Edwards)

2

1

1

1

4

1

2

6

1

4

1

Anomura:

Paguristes sulcatus Baker 1

Cirripedia :

Balanus trigonus Darwin 4

Pycnogonida:

Achelia sp.

2

Nymphon molleria 1

Echinodermata :

Ophiuroidea :

Ophiothrix caespitosa Lyman 13

${ }^{+}$Pholiostigma watsonae (Baker m.s.) 2

*Ophiacantha alternata A. M. Clark 1

$\begin{array}{ll}\text { Ophiactis resiliens Lyman } & 1\end{array}$

Holothuroidea :

Pentacta doliolum (Pallas)

*Neocucumis? watasei (Ohshima)

+Thyone sp.

Ascidiacea :

PISCES

Polycarpa pedata Herdman

Gobiosocidae 


\section{$2 \mathrm{BHL}$ Biodiversity Heritage Library}

Watson, Jeanette. 1979. "Biota of a temperate shallow water reef." Proceedings of the Linnean Society of New South Wales 103, 227-235.

View This Item Online: https://www.biodiversitylibrary.org/item/109057

Permalink: https://www.biodiversitylibrary.org/partpdf/287886

\section{Holding Institution}

MBLWHOI Library

\section{Sponsored by}

Boston Library Consortium Member Libraries

\section{Copyright \& Reuse}

Copyright Status: In copyright. Digitized with the permission of the rights holder.

License: http://creativecommons.org/licenses/by-nc-sa/3.0/

Rights: https://biodiversitylibrary.org/permissions

This document was created from content at the Biodiversity Heritage Library, the world's largest open access digital library for biodiversity literature and archives. Visit BHL at https://www.biodiversitylibrary.org. 